\title{
Semi-selective medium for Fusarium graminearum detection in seed samples
}

\author{
Marivane Segalin \& Erlei Melo Reis ${ }^{1}$
}

${ }^{1}$ Bolsista do CNPq, Universidade de Passo Fundo, Faculdade de Agronomia e Medicina Veterinária, Cx. Postal 611, Passo Fundo-RS, Brazil 99001-970.

Autor para correspondência: Erlei Melo Reis (erleireis@tpo.com.br)

Data de chegada: 16/06/2005. Aceito para publicação em: 10/02/2010.

\section{ABSTRACT}

Segalin, M. \& Reis, E. M. Semi-selective medium for Fusarium graminearum detection in seed samples. Summa Phytopathologica, v.36, n.4, p.338-341, 2010.

Fungi of the genus Fusarium cause a variety of difficult to control diseases in different crops, including winter cereals and maize. Among the species of this genus Fusarium graminearum deserves attention. The aim of this work was to develop a semi-selective medium to study this fungus. In several experiments, substrates for fungal growth were tested, including fungicides and antibiotics such as iprodiona, nystatin and triadimenol, and the antibacterial agents streptomycin and neomycin sulfate. Five seed samples of wheat, barley, oat, black beans and soybeans for $F$. graminearum detection by using the media Nash and Snyder agar (NSA), Segalin \& Reis agar (SRA) and one- quarter dextrose agar (1/4PDA; potato $50 \mathrm{~g}$; dextrose $5 \mathrm{~g}$ and agar $20 \mathrm{~g}$ ), either unsupplemented or supplemented with various concentrations of the antimicrobial agents cited above. The selected components and concentrations $\left(\mathrm{g} . \mathrm{L}^{-1}\right)$ of the proposed medium, Segalin \& Reis agar (SRA-FG), were: iprodiona 0.05 ; nystatin 0,025 ; triadimenol 0.015 ; neomycin sulfate 0.05 ; and streptomycin sulfate, 0.3 added of $1 / 4$ potato sucrose agar. In the isolation from seeds of cited plant species, the sensitivity of this medium was similar to that of NSA but with de advantage of maintaining the colony morphological aspects similar to those observed in potato-dextrose-agar medium.

Keywords: Small grains scab, head blight, Gibberella zeae, seed assay.

\section{RESUMO}

Segalin, M. \& Reis, E. M. Meio semi-seletivo para detecção de Fusarium graminearum em amostras de sementes. Summa Phytopathologica, v.36, n.4, p.338-341, 2010.

Os fungos do gênero Fusarium causam doenças de difícil controle, em diferentes culturas, inclusive em cereais de inverno e milho. Dentre as espécies do gênero, merece destaque Fusarium graminearum. Desenvolver um meio semi-seletivo para detecção e edificação de $F$. graminearum em sementes, foi o objetivo do presente trabalho. Em diversos experimentos foram testados diferentes meios para meio semi-seletivo acrescido ou não de agentes microbianos. Os fungicidas testados forma iprodiona, nistatina, triadimenol, e os bactericidas sulfato de estreptomicina e sulfato de neomicina. Foram testadas cinco amostras de sementes de trigo, cevada, aveia, feijão comum e soja para a detecção de $F$. graminearum utilizando os meios Nash \&
Snyder Ágar (NSA), Segalin \& Reis ágar (SRA) e 1/4 batata-sacaroseágar (1/4 BDA; $50 \mathrm{~g}$ de batata, $5 \mathrm{~g}$ de dextrose e $20 \mathrm{~g}$ de ágar), todos suplementados ou não com os agentes antimicrobianos citados. Os componentes e as concentrações (g. $\left.\mathrm{L}^{-1}\right)$ que compõem o meio semiseletivo proposto, Segalin \& Reis ágar (SRA-FG), foram: iprodiona 0,05 ; nistatina 0,025 ; triadimenol 0,015 ; sulfato de estreptomicina 0,3 ; sulfato de neomicina 0,05 , acrescidos ao meio basal de $1 / 4$ batatadextrose-ágar. Em isolamentos, a partir das sementes espécies vegetais citadas, o meio semi-seletivo proposto (SRA-FG) apresentou a mesma sensibilidade do meio NSA e com a vantagem de manter os aspectos morfológicos das colônias semelhantes aquelas observadas meio BDA.

Palavras-chave adicionais: Fusariose, giberela, Gibberella zeae, patologia de sementes.

Several fungal species belonging to the genus Fusarium cause agriculturally important diseases in a variety of plants. The pathogen Fusarium graminearum Schwabe, teleomorph Gibberella zeae (Schwein.) Petch, is the causal agent of wheat (Triticum aestivum $\mathrm{L}$.) head blight also known as giberela ear rot and maize (Zea mays L.) stem and cob rot (2). This parasite has a wide geographical distribution and attacks a large number of crops causing qualitative and quantitative damage, which can affect agricultural production (6). Head blight of wheat is particularly important in the state of Rio Grande do Sul, Brazil, where wheat is extensively grown (13). In the south of Brazil ecological group II occurs (1, 11). A detailed knowledge of the survival and dissemination mechanisms of pathogenic fungi is important in developing control measures for difficult-to-control fungal plant pathogens. Selective or semi-selective culture media, which act by excluding non-target fungi and bacteria, are important tools for fungal isolation, purification and quantification and for investigating the detailed biology of fungi, being especially useful for slow growing organisms $(3,4,12)$. However, the media currently available for Fusarium do not meet criteria such as sensitivity and selectivity and ability to allow the development of Fusarium colonies with consistent morphological characteristics and pigmentation (9).

Several selective or semi-selective culture media have been developed for the isolation of Fusarium species, including the most widely-used culture medium Nash-Snyder agar (NSA) (7). However, the NSA medium often does not maintain the 
characteristic morphology of $F$. graminearum, which does not sporulate easily on certain artificial culture medium. Accurate identification of $F$. graminearum is only possible after sub-culture onto potato dextrose agar (PDA) (10) on which this pathogen produces easily recognizable rose-red colonies with yellowish to chestnut aerial mycelia $(2,9)$. However, the fact that at least two media are necessary for the formal identification of $F$. graminearum means that the isolation and identification process is more complex and costly and that contamination of cultures can occur on the non-selective medium, leading to possible identification errors.

The aim of this work was to develop a sensitive and semiselective culture medium for the isolation and identification in situ of $F$. graminearum from seed samples.

The $F$. graminearum isolate used in this study was isolated from wheat seeds in 2001/2002 and was deposited at the collection of University of Passo Fundo, Laboratory of Plant Pathology FG 21-06 and preserved in PDA slants at $5^{\circ} \mathrm{C}$. During the trials $F$. graminearum was maintained in potato-dextrose-agar (PDA) plates and serially transferred every month. For each experiment fresh cultures were prepared by inoculating PDA plates and incubating them at $25^{\circ} \mathrm{C} \pm 2{ }^{\circ} \mathrm{C}$ under a $12 \mathrm{~h}$ light: $12 \mathrm{~h}$ dark photoperiod provided by day light fluorescent tubes (Osram $40 \mathrm{~W}$ ) for six to seven days until the plates were completely covered with mycelia. A sterilized $5.0 \mathrm{~mm}$ diameter cork borer was used to cut mycelial disks which were transferred to the center of $9.0 \mathrm{~cm}$ diameter Petri dishes containing the previously selected media and incubated as described above. Radial growth was measured every day by using a digital vernier caliper (Mitutoyo Digimatic Caliper - Mitutoyo Sul Americana Ltda, SP).The experiments were evaluated during seven days when the PDA control plates were completely covered with mycelia.

Culture media were compared in order to select one that allowed F. graminearum growth while maintaining the morphologic characteristics seen when this organism is grown on PDA (4). The media tested were: maize meal agar [CMA, containing g.L $\mathrm{L}^{-1}$ maize meal, 60; and agar, 20]; Czapek agar [CZA, containing (g. L $\left.{ }^{-1}\right)$ : sucrose, 30; $\mathrm{NaNO}_{3}, 2 ; \mathrm{KH}_{2} \mathrm{PO}_{4}, 1 ; \mathrm{MgSO}_{4} .7{ }_{2} 0,0.5 ; \mathrm{KCl}, 0.5 ; \mathrm{FeSO}_{4} .7 \mathrm{H}_{2} 0$, 0.01; and agar, 20]; Nash-Snyder agar [NSA, containing (g. $\left.\mathrm{L}^{-1}\right)$ : peptone, $15, \mathrm{KH}_{2} \mathrm{PO}_{4}, 1, \mathrm{MgSO}_{4}, 0.5, \mathrm{PCNB}$ (pentachloronitrobenzene) $7.7 \mathrm{~g}$ a.i., neomycin sulfate, $0.12 \mathrm{~g}$ in $100 \mathrm{~mL} \mathrm{H}_{2} 0$, streptomycin sulfate, $1 \mathrm{~g}$ in $100 \mathrm{~mL} \mathrm{H}_{2}$, agar, 15, distilled water, $700 \mathrm{~mL}$ ]; potato dextrose agar [PDA, containing g. $\mathrm{L}^{-1}$ : potato, 200; dextrose, 20; agar, 20]; PDA supplemented with 0.2 g.L $\mathrm{L}^{-1}$ streptomycin sulfate (PDA$\mathrm{S})$; one-quarter strength PDA [1/4PDA, containing g.L $\mathrm{L}^{-1}$ : potato, 50; dextrose, 5; agar, 20]; 1/4PDA supplemented with 0.2 g.L.-1 streptomycin sulfate (1/4PDA-S). In some cases, we used a commercial PDA (Acumedia, Lansing, MI, USA), containing (g.L $\left.{ }^{-1}\right)$ : dextrose, 20; dehydrated potato, 4; agar, 20. The media were made up to one liter with distilled water and autoclaved at $103 \mathrm{KPa}\left(121^{\circ} \mathrm{C}\right)$ for $15 \mathrm{~min}$. All the media were used either unsupplemented or supplemented after autoclaving with various combinations of the filter-sterilized antifungal agents and antibiotics described below.

To screen possible selective agents radial growth experiments were conducted using $F$. graminearum PDA mycelial disks placed onto unsupplemented CMA, CZA, NSA, PDA, 1/4PDA, PDA-S and 1/ 4PDA-S or the same media supplemented with antifungal and six antibacterial agents at the following concentrations $\left(\mathrm{g} . \mathrm{L}^{-1}\right): 0.02,0.03$, $0.04,0.05$, and 0.06 for iprodione (IF) and guazatine (GU); 0.01, $0.015,0.02,0.025$, and 0.03 for nystatin (NY); triadimenol (TR); 0.1, $0.15,0.02,0.025$, and 0.03 ; for streptomycin sulfate (ST) $0.1,0.2$, $0.3,0.4$, and 0.5 ; and $0.025,0.05,0.1,0.15$, and 0.2 for neomycin sulfate (NY). Radial growth was measured as described above and the colony color assessed with the aim of selecting the concentrations of these agents which allowed the highest $F$. graminearum growth and which did not alter the pigmentation in the medium. The unsupplemented media and PDA acted as control.

Five different cultivars of barley (Hordeum vulgare L.) (BRS 127, BRS 195, BRS 255, MN 698, and MN 743), oat (Avena sativa L.) (UPF 18, UPF 19, UPF 21, and UPF 22) and wheat (Triticum aestivum L.)( BR 18, BR 23, BRS 177, BRS 179, and Fundacep 30) and the legumes common black bean (Phaseolus vulgaris L.) (Bionobre, Nobre, Soberano, Uirapuru, Valente), soybean (Glycine $\max$ Merr.) (M 8001, 6001, 6401, 6445, and 8100) were tested for the presence of $F$. graminearum on seeds using NSA, SRA-FG and PDA semi-selective for $F$. graminearum selected in the experiments described above. SRA-FG contained 1/4PDA supplemented with $\left(\mathrm{g} . \mathrm{L}^{-1}\right)$ : iprodione, 0.05 ; neomycin sulfate 0.05 ; nystatin, 0.025 ; streptomycin sulfate, 0.3 ; and triadimenol 0.015 . In some cases the streptomycin concentration was raised to $1 \mathrm{~g} . \mathrm{L}^{-1}$ to control bacteria and sometimes 0.005 g.L $\mathrm{L}^{-1}$ of pentachloronitrobenzene was added to suppress yeasts.

For each plant specie tested, 25 seeds were placed in $11 \mathrm{~cm} \mathrm{x}$ $11 \mathrm{~cm} \times 3.5 \mathrm{~cm}$ germination boxes (Gerboxes) containing NSA, SRA-FG or PDA at $25^{\circ} \mathrm{C}$ :f: $20^{\circ} \mathrm{C}$ under a $12 \mathrm{~h}$ light $12 \mathrm{~h}$ dark photoperiod, illumination being provided by $40 \mathrm{~W}$ daylight-type fluorescent tubes (Osram) placed $35 \mathrm{~cm}$ to $40 \mathrm{~cm}$ above the boxes. Four replicates (100 seeds) were used for each species, totaling 400 seeds evaluated. After seven days, the seeds were placed under a stereomicroscope $(50 \mathrm{x})$ to evaluate the presence of $F$. graminearum and the percentage incidence of $F$. graminearum incidence per colony developed from the seeds was calculated.

The experiment was analyzed as a randomized factorial with two factors (a) culture media and plant species using ANOVAR and the Tukey-test $(\mathrm{P}<0.05$.

Most selective media are, in fact, semi-selective since they allow the development of other organisms apart from the target organism which means that the medium developed by us may also be useful for taxa other than $F$. graminearum.

Previous experiments (data not showed) aimed at selecting fungicides for the control of seed-transmitted pathogenic fungi of winter cereals and maize showed that $F$. graminearum was not affected by the fungicides guazatine, iprodione and triadimenol thus we chose these fungicides for the basis of our semi-selective media. We also tested the antibacterial agent neomycin, effective against Gram-positive bacteria and the fungi Rhizopus and Mucor, and the broad-spectrum antibiotic streptomycin sulfate along with the broad-spectrum antifungal agent nystatin, all of which had been shown to have little effect on Fusarium species (12).

F. graminearum radial growth experiments showed that 1/4PDA was the best basal medium and the growth was slower on this medium on PDA-S. Slow growth of the contaminants was used as a criterion for the best semi-selective media. The medium 1/4 PDA also preserved all morphological characteristics, useful for identification and also allowed abundant sporulation of $F$. graminearum, which usually does not sporulate on some artificial media (2). The other media were not as satisfactory for $F$. graminearum identification because colony morphology on these media was altered. We therefore chose 1/4PDA as the basal culture medium to test the antibiotic and antifungal selective agents and compared this medium with the commercial PDA.

Previous work has shown that the fungicide iprodione is relatively non-toxic to $F$. graminearum; our experiments showed that when iprodione was incorporated into $1 / 4 \mathrm{PDA}$ at $0.06 \mathrm{~g} .{ }^{\mathrm{L}-1}$ 
the resultant medium (1/4 PDA-IP60) allowed the second highest radial growth following the PDA control. However, the most typical $F$. graminearum colony characteristics occurred on 1/4PDA supplemented with 0.05 g.L. $\mathrm{L}^{-1}$ iprodione (1/4PDA-IP50), thus this concentration was selected for the final semi-selective medium. All iprodione supplemented media allowed better $F$. graminearum radial growth than the NSA control.

$F$. graminearum radial growth on media supplemented with the fungicide guazatine was lower than on the control media and inversely proportional to guazatine concentration, leading us to discard the use of guazatine as a semi-selective agent for $F$. graminearum.

The effects of nystatin were also inversely proportional to the radial growth of $F$. graminearum and there was some slight change in colony color. Nevertheless we decided to incorporate $0.025 \mathrm{~g}$. $\mathrm{L}^{-}$ ${ }^{1}$ of nystatin into the final medium because this was the highest concentration which did not produce a noticeable color change in the $F$. graminearum colonies but allowed higher growth than NSA medium. The 1/4PDA-IP50 control resulted in the lowest $F$. graminearum radial growth while 1/4PDA supplemented with 0.01 g.L $\mathrm{L}^{-1}$ iprodione (1/4PDA - IP10) led to the second highest radial growth, which was exceeded only by the 1/4PDA control; however $0.01 \mathrm{~g} . \mathrm{L}^{-1}$ iprodione did not control contaminant fungi.

For media containing streptomycin sulfate, $F$. graminearum radial growth was highest in the presence of 0.2 g.L. $\mathrm{L}^{-1}$ and on 1/ 4PDA and 1/4PDA supplemented with 0.05 g.L. - $^{-1}$ iprodione and 0.025 g.L.-1 nystatin (1/4PDA-IP50/NY25). Since there was little difference in $F$. graminearum radial growth between the concentrations 0.2 g. $\mathrm{L}^{-1}$ and $0.3 \mathrm{~g} . \mathrm{L}^{-1}$ concentrations streptomycin, we decided to select the latter to ensure a more effective selective medium against bacteria. We also found that NSA resulted in the lowest $F$. graminearum radial growth, compared with the other media tested.

When the antibiotic neomycin sulfate was tested we found that compared with NSA, 1/4PDA and IP50/NY25 the lowest $F$. graminearum radial growth occurred at $0.1,0.15$ and $0.2{\mathrm{~g} . ~ \mathrm{~L}^{-1}}^{-1}$ neomycin and that at these concentrations the fungal colonies were bleached or whitened. However, when 1/4PDA was supplemented with $0.05 \mathrm{~g}$. $\mathrm{L}^{-1}$ neomycin (1/4PDA-NE50) there was little difference between $F$. graminearum radial growth on this media and that on NSA, and 1/4PDA-NE50 had the advantage of causing no alteration in the color of $F$. graminearum colonies.

In the experiment with the fungicide triadimenol $F$. graminearum radial growth was highest on the unsupplemented 1/4PDA control and 1/4PDA supplemented with $0.3 \mathrm{~g} \mathrm{~L}^{-1}$ streptomycin sulfate, $0.05 \mathrm{~g} . \mathrm{L}^{-1}$ of both neomycin sulfate and iprodione, $0.05 \mathrm{~g} . \mathrm{L}^{-1}$ nystatin and $0.01 \mathrm{~g} . \mathrm{L}^{-1}$ triadimenol but we decided that $0.01 \mathrm{~g} . \mathrm{L}^{-1}$ a triadimenol was the best concentration to inhibit contaminant fungi since it allow $F$. graminearum growth without altering its characteristic coloration.

Based on $F$ graminearum radial growth the most suitable semiselective medium for $F$. graminearum was that consisting of 1/ 4PDA supplemented with $\left(\mathrm{g} . \mathrm{L}^{-1}\right)$ : streptomycin sulfate, 0.3 ; iprodione, 0.05; neomycin sulfate, 0.05; nystatin, 0.025; and triadimenol 0.015. This medium was denominated Segalin \& Reis semi-selective for $\mathrm{F}$ graminearum (SRA-FG). 1/4PDA can be made in the laboratory or prepared from commercial media (Acumedia, Lansing, MI, USA) by using 1/4 of the recommended quantity with the addition of extra agar to give a final agar concentration of $20 \mathrm{~g} . \mathrm{L}^{-1}$.

Standard culture media such as PDA support the growth of many fungal species and often require specialized pretreatment samples, and errors in such processes can compromise the investigation validity due to the presence of undesirable contaminants $(5,8)$. In many agronomic situations, especially the examination of seeds for plant pathogenic fungi, semi-selective media can reduce the need for asepsis and thus save time and material.

Reis (12) developed a semi-selective medium that restricts the development of undesirable fungi and bacteria but is selective for the pathogen Bipolaris sorokiniana (Sacc.) Shoem. and other members of the Dematiaceous hyphomycetes such as Alternaria and Drechslera, facilitating detailed studies on the biology and ecology of the

Table 1. Sensitivity of potato dextrose agar (PDA), Nash \& Snyder agar (NSA) and Segalin-Reis agar (SRA-FG) for the detection of Fusarium graminearum on seeds of different cultivars of the cereals wheat, barley, oat, beans, and soybean.

\begin{tabular}{|c|c|c|c|}
\hline \multicolumn{4}{|c|}{ Incidence of $F$. graminearum $(\%)^{1}$ and typical colony color ${ }^{2}$} \\
\hline Plant species/cultivars & PDA $^{3}$ & $\mathbf{N S A}^{3}$ & SRA-FG ${ }^{3}$ \\
\hline \multicolumn{4}{|l|}{ Cereals } \\
\hline \multicolumn{4}{|l|}{ Wheat } \\
\hline BR 18 & $23.00 \mathrm{a}$ & $97.50 \mathrm{a}$ & $96.50 \mathrm{a}$ \\
\hline BR 23 & $7.75 \mathrm{~b}$ & $3.00 \mathrm{~b}$ & $7.00 \mathrm{~b}$ \\
\hline FUND 30 & $5.25 \mathrm{~b}$ & $3.00 \mathrm{~b}$ & $2.75 \mathrm{c}$ \\
\hline BRS 179 & $2.75 b c$ & $2.00 \mathrm{~b}$ & $0.50 \mathrm{c}$ \\
\hline BRS 177 & $1.00 \mathrm{c}$ & $0.25 b$ & $0.50 \mathrm{c}$ \\
\hline $\operatorname{Mean}(C V=11.96 \%)$ & $7.75 \mathrm{~B}^{+}$ & $21.10 \mathrm{~A}^{-}$ & $21.45 \mathrm{~A}^{+}$ \\
\hline \multicolumn{4}{|l|}{ Barley } \\
\hline BRS 195 & $61.50 \mathrm{a}$ & $100.0 \mathrm{a}$ & $99.25 \mathrm{a}$ \\
\hline BRS 255 & $13.00 \mathrm{~cd}$ & $87.75 \mathrm{bc}$ & $91.75 \mathrm{ab}$ \\
\hline EMB 127 & $4.00 \mathrm{~d}$ & $79.00 \mathrm{c}$ & $80.75 \mathrm{~b}$ \\
\hline MN 698 & $8.00 \mathrm{c}$ & $94.75 \mathrm{ab}$ & $93.75 \mathrm{a}$ \\
\hline MN 743 & $47.75 b$ & $99.00 \mathrm{ab}$ & $97.00 \mathrm{a}$ \\
\hline Mean $(C V=8.39 \%)$ & $28.85 \mathrm{~B}^{+}$ & $92.10 \mathrm{~A}^{-}$ & $92.50 \mathrm{~A}^{+}$ \\
\hline \multicolumn{4}{|l|}{ Oat } \\
\hline UPF 18 & $0.00 \mathrm{~b}$ & $0.25 \mathrm{~b}$ & $0.25 \mathrm{~b}$ \\
\hline UPF 19 & $2.25 a b$ & $10.00 \mathrm{a}$ & $9.50 \mathrm{a}$ \\
\hline UPF 20 & $1.25 \mathrm{ab}$ & $2.75 \mathrm{~b}$ & $3.00 \mathrm{~b}$ \\
\hline UPF 21 & $0.25 \mathrm{~b}$ & $1.00 \mathrm{~b}$ & $0.75 \mathrm{~b}$ \\
\hline UPF 22 & $4.50 \mathrm{a}$ & $9.50 \mathrm{a}$ & $8.50 \mathrm{a}$ \\
\hline $\operatorname{Mean}(C V=55.07 \%)$ & $1.65 \mathrm{~B}^{+}$ & $4.70 \mathrm{~A}^{-}$ & $4.40 \mathrm{~A}^{+}$ \\
\hline \multicolumn{4}{|l|}{ Legumes } \\
\hline \multicolumn{4}{|l|}{ Black beans } \\
\hline Bionobre & $0.05 \mathrm{a}$ & $0.00 \mathrm{a}$ & $0.25 \mathrm{a}$ \\
\hline Nobre & $0.25 \mathrm{a}$ & $1.00 \mathrm{a}$ & $0.50 \mathrm{a}$ \\
\hline Soberano & $0.00 \mathrm{a}$ & $0.50 \mathrm{a}$ & $0.00 \mathrm{a}$ \\
\hline Uirapuru & $0.00 \mathrm{a}$ & $1.75 \mathrm{a}$ & $1.00 \mathrm{a}$ \\
\hline Valente & $0.00 \mathrm{a}$ & $1.25 \mathrm{a}$ & $1.25 \mathrm{a}$ \\
\hline Mean $(C V=177.21 \%)$ & $0.15 B^{+}$ & $0.90 \mathrm{~A}^{-}$ & $0.60 \mathrm{~B}^{+}$ \\
\hline \multicolumn{4}{|l|}{ Soybeans } \\
\hline M 8001 & $6.50 \mathrm{a}$ & $6.25 \mathrm{a}$ & $2.75 \mathrm{a}$ \\
\hline 6401 & $1.50 \mathrm{~b}$ & $6.50 \mathrm{a}$ & $5.00 \mathrm{ab}$ \\
\hline 6445 & $0.00 \mathrm{~b}$ & $0.75 \mathrm{~b}$ & $0.25 \mathrm{bc}$ \\
\hline 6001 & $0.00 \mathrm{~b}$ & $0.50 \mathrm{~b}$ & $0.25 \mathrm{c}$ \\
\hline 8100 & $0.00 \mathrm{~b}$ & $0.75 b$ & $0.50 \mathrm{c}$ \\
\hline $\operatorname{Mean}(C V=57.45 \%)$ & $1.60 \mathrm{~B}^{+}$ & $2.95 \mathrm{~A}^{-}$ & $1.75 \mathrm{~B}^{+}$ \\
\hline
\end{tabular}

${ }^{1}$ After seven days, the seeds were evaluated for $F$. graminearum in petry plates containing PDA, NSA and SRA-FG media. Plates were incubated as described above and calculating the percentage incidence of $F$. graminearum.

Typical colony color (+) and different (-).

${ }^{3}$ Means followed by the same lower-case letter in the columns or upper-case letter in the rows did not differ statistically (Tukey-test, $\mathrm{P}=5 \%$ ). $\mathrm{CV}=$ Coefficient of variation. 
pathogens.

The seed tests showed that, compared with NSA, SRA-FG exhibited statistically similar sensitivity and selectivity for the detection of $F$. graminearum in most of the seeds evaluated (Table 1), and SRA-FG had the advantage of facilitating the identification of $F$. graminearum based on colony color and morphology.

For some samples, the streptomycin concentration had to be raised to $1 \mathrm{~g} . \mathrm{L}^{-1}$ to control bacteria and 0.005 g.L-1 pentachloronitrobenzene was added to suppress yeasts. For the legumes $P$. vulgaris and $G$. $\max$, which normally have a low incidence of $F$ graminearum, the percentage of $F$. graminearum incidence on NSA was statistically higher than on SRA-FG and PDA, whereas for the cereals Triticum aestivum $\mathrm{L}$, Hordeum vulgare $\mathrm{L}$ and Avena sativa $\mathrm{L}$ there was no statistical difference between NSA and SRA-FG (Table 1). Nash \& Snyder (7) medium is considered standard for the isolation of Fusarium species but our results confirm the usefulness of SRA-FG, a medium that facilitates the morphological identification of $F$. graminearum.

The SRA-FG medium described in this paper is sufficiently sensitive and selective for $F$. graminearum identification and has the advantage over other media of maintaining the morphology and coloration of $F$. graminearum colony while inhibiting the growth of other microorganisms. This medium may help in carrying out other detailed biological and epidemiological studies on $F$. graminearum. Work is currently underway testing SRA-FG medium for its ability to recover $F$. graminearum from other crops as well as from roots, crop residues and soil.

\section{REFERENCES}

1. Aoki, T. \& O’Donell, K. Morphological and molecular characterization of Fusarium pseudograminearum sp. no., formerly recognized as the group I population of $F$. graminearum. Mycolo- gia, New York v. 9, p.597-609, 1999.

2. Booth, C. The Genus Fusarium. Commonwealth Mycological Institute, Kew, UK, 237p, 1971.

3. Dodman, R. L. \& Reinke, J. R A selective medium for determining the population of viable conidia of Cochliobolus sativus in soil. Australian Journal of Agricultural Research, Victoria v. 33, p.287-291, 1982.

4. Fernandez, M. R Manual para Laborat6rio de Fitopatologia. Passo Fundo: EMBRAPA-CNPT, 128p, 1993.

5. Machado, J. da C. Patologia de sementes: fundamentos e aplicações. Ministério da Educação, Brasília, Lavras, ESAL/FAEPE, $106 \mathrm{p}, 1988$.

6. Mauler-Machnik, A. \& Zahn, K. Ear fusariosis in wheat - new findings on their epidemiology and control with Folicur. Pflanzenschutz-Nachrichten. Bayer, Leverkusen v.47, p 133-160, 1994.

7. Nash, S.M. \& Snyder, W. C. Quantitative estimations by plate counts of propagules of the bean root rot Fusarium in field soils. Phythopatology, St. Paul v.52, p.567-572, 1962.

8. Nasser, L. C. B. Testes de sanidade de sementes de trigo (Triticum aestivum L.). In: Patologia de sementes, Eds. Soave, 1. \& Wetzel da Silva, M.M. V. Fundação Cargill, Campinas-SP, Brasil, pp 469477, 1987.

9 Nelson, P. E and Toussoun, T. A. A pictorial guide to the identification of Fusarium species according to the taxonomic system of Snyder and Hansen. The Pennsylvania State University Press, London. 51 p, 1968.

10. Onions, A. H. S., Allsopp, D. \& Eggins, H.O.W. Smith's Industrial Mycology. Seventh Edition. Edward Arnold, London, p. 132-133, 1981

11. Reis, E. M. Caracterização da população de Fusarium graminearum no sul do Brasil. Fitopatologia Brasileira, Brasília v.11, p.527-533, 1986.

12. Reis, E. M. Selective medium for isolating Cochliobolus sativus from soil. Plant Disease, St. Paul v. 67, p. 68-70, 1983.

13. Reis, E. M. Doenças do trigo III: Giberela (2a ed. revista e ampliada) São Paulo, 13p, 1988 